\title{
Is Higher Education Ambivalent \\ Towards Inclusion of Non-Formal \\ Qualifications in National Qualifications \\ Frameworks (NQFs)?
}

\section{A Policy-Learning Analysis of Seven Country Reports}

\author{
Anne Murphy and Horacy Dębowski
}

\begin{abstract}
Abbreviations
ENQA European association for quality assurance in higher education

EQF European qualifications framework

NQF National Qualifications Framework

OECD Organisation for economic cooperation and development

QAA Quality assurance authority

QQI Qualifications and Quality Ireland

RNFIL Recognition of non-formal and informal learning

RPL Recognition of prior learning

SCQFP Scottish credit and qualifications framework partnership

SQA Scottish Qualifications Authority

VNFIL Validation of non-formal and informal learning
\end{abstract}

\section{Introduction}

There is some legitimacy in arguing that NQFs are sufficiently too-recent to expect to find a robust body of critical publications which explores resistance to them or which questions their underlying assumptions (Fernie and Pilcher 2009). It is evident that most literature about NQFs is narrative, descriptive, evaluative, or

\footnotetext{
A. Murphy ( $₫)$

Dublin Institute of Technology, Dublin, Ireland

e-mail: anne.murphy@dit.ie

H. Dębowski

Warsaw School of Economics, Warsaw, Poland

e-mail: horacy.debowski@sgh.waw.pl

(C) The Author(s) 2018
}

A. Curaj et al. (eds.), European Higher Education Area: The Impact of Past and Future Policies, https://doi.org/10.1007/978-3-319-77407-7_33 
advocacy, is aspirational and optimistic, with very little critique, except perhaps in the cases of the NQFs of South Africa, New Zealand and Australia (Raffe 2012) and in the cases of impact evaluations in Ireland and the UK. This paper seeks to address this dearth of critique in a small way and to contribute to evidence-based research about one very focused aspect of the actual functioning of NQFs in national contexts: how non-formal qualifications are included in or excluded from NQFs, and what this reality might mean for the expectation that NQFs and the Bologna framework for higher education can actually provide greater transparency, readability and comparability of qualifications for learners and for the labour market.

The paper is relevant for the higher education sector in particular since, together with the formal school and VET systems, it populates the rigid spine of most NQF architectures and is less likely to accommodate disturbance of that position to accommodate new non-formal providers and new types of qualifications representative of market qualifications, post-secondary education or adult education.

Readers should consider the paper as a minor contribution to opening a wider critical debate around the areas of tension with regard to control of NQFs, particularly at higher education level, mindful that comparative analysis of data from the seven country reports included later below was still at an initial stage at the time writing.

\section{Global Data Versus Local Realities}

According to the Global Inventory of Regional and National Qualifications Frameworks produced by UNESCO, the European Training Foundation and Cedefop in 2015, one-hundred and ninety-three states had already developed NQFs based on a learning outcomes paradigm. In the Introduction to the Inventory, the authors comment on this figure by summarising the dominant meta-policy discourse around the purpose of NQFs, as follows:

\footnotetext{
Given the diversity of country contexts, it is remarkable how much consensus exists around the world that learning outcomes based qualification frameworks are appropriate tools for the reform and expansion of educational and training provision in ways that will raise skills levels, improve labour market productivity and contribute to sustainable development.
}

However, there are competing discourses around the purpose, implementation and impacts of NQFs assumed in this comment and, indeed, there are competing discourses within the inventory itself. There are also divergent conclusions around precisely how many of the 193 NQFs in the inventory have moved beyond the "legal document" stage. Deij and Graham conclude in their thematic chapter in the inventory that in most cases NQFs remain empty of qualifications. If their conclusion also accurately reflects the state-of-play with regard to NQFs at the end of 2017 , then any analysis of the attitudes of higher education towards NQFs on a global level would have little validity or acceptability as evidence-based research. 
For the purpose of useful comparability in this paper, the global scope of NQFs is delimited to EU member states where the Bologna framework, the EQF-LLL and an NQF have at least been worked through to a stage where articulation across the NQF and the meta frameworks has been established, even if an NQF may not be inclusive of all types and sectors of education and training at this time. While policy learning from early NQF adopters such as South Africa, New Zealand and Australia inform the conceptual understanding for this paper, their data are not explicitly included.

\section{Questions Posed in the Paper and the Matter of Transparency}

So, two broad questions are posed in this paper and some evidence offered in response. The two questions are:

i. Is there any evidence that higher education is actually ambivalent to the development and implementation of inclusive NQFs?

ii. Is higher education ambivalent to, or indeed hostile to, the "opening up" of NQFs by including "non-formal qualifications" gained outside of formal school, VET and university sectors?

The paper addresses the first question by drawing on relevant policy documents and critical publications from the HE sector itself and from analysis by critical commentators on frameworks generally.

The second question is more complex as it assumes a shared understanding of concepts, terminology and legally-based operational systems. It was not possible to explicitly conduct primary research of sufficient depth and breadth for this paper to offer credible primary data to answer this question fully. Instead, the authors drew both from published literature and from data generated for seven EU Country Reports produced by the Erasmus+ Project- "NQF-IN"-Developing organisational and financial models for inclusion of non-formal qualifications in NQFs in which they were both involved as designers of the methodology for the reports and as authors of the reports for Ireland and Poland respectively (Murphy 2017; Sławiński et al. 2017).

As the methodology for producing the Country Reports did not include direct exploration of HE's attitudes to the inclusion of non-formal qualifications in NQFs as a discrete topic of research, a proximal validity was assumed for this paper by drawing out data that exposed the local reality and by reproducing relevant data accurately from the reports themselves with permission from the original authors, followed by identification of themes and issues relevant to the transparency of qualifications, or their degree of an opacity, as an indicator of ambivalence or hostility.

For the purpose of this paper, the working definition of "non-formal qualification" is a qualification achieved outside of state-supported education and training systems. This definition includes, inter alia, qualifications provided by private 
providers, commercial companies, voluntary/not-for-profit organisations, regulated sectors, and Ministries of Government.

\section{Structure of the Paper}

The paper is organised into three further parts. The first part discusses the policy backdrop to considering non-formal qualifications as a discrete sector vis-á-vis qualifications frameworks and includes selected academic critique of both policy directions and academic practice in this regard.

In the second part relevant data from the Erasmus+ Research Project "NQF-IN" are presented and analysed in relation to the two questions posed by the paper.

The final part tentatively draws out the most obvious policy challenges for the inclusion of non-formal qualifications in NQFs and how these challenges might require additional responses from higher education generally. It also suggests where additional research could usefully contribute.

\section{Relevant Policy Themes and Academic Issues}

The themes selected of immediate relevance are: differentiation in the architecture of NQFs; limiting epistemic access; flaws in RPL/VNFIL nomenclatures underpinning policy; learning outcomes as a barrier to inclusion; the reality of the non-formal sector.

\section{Policy Matters: Embedded Differentiation and Credentialising Powers}

The reality that communicative frameworks with sub-frameworks start from what already exists and intend to make greater sense of complex contexts is unquestioned in this paper. Perhaps one of the unintended consequences of communicative frameworks is greater embedding of what already exists in "soft laws" (Young 2010), including the locus of power in deciding what, if any, reforms will follow. Communicative frameworks may also be less self-critical, thereby warding off resistance to established practices, assumptions and sense of entitlement among the poser elites.

Fernie and Pilcher argued provocatively in 2009 that the university sector in Scotland-where the "communicative" SCQF is long-established-willingly engages in reforming activity when it is more symbolic than substantive, particularly if their control of its own sector, and indirectly of the school sector, is not 
being diminished by decision-makers outside their sector. Thus, the sector's preference at that time to engage with ERHEA quality frameworks than with local framework bodies which may seek to impose innovations and more diverse stakeholder involvement: described by Young (2010) as illustrative of the "inescapable conservative role of higher education".

Young argues that differentiation will continue in spite of EQF rhetoric around the equalising impact of meta-framework levels and titles. We also argue that, in this regard, the credentialising power of the HE sector is under no threat while differentiation continues.

\section{Epistemic Access Versus Widening Participation}

Ideological tensions around who should have access to the social and economic capital of higher education qualifications are not new. Dual systems which strictly regulate access to higher education persist in the EU despite the rhetoric of homogeneity around a contextual equivalence of learning, levelling of qualifications, and removal of boundaries between different forms of knowledge as promoted by the EQF meta-framework (Karseth and Solbrekke 2010; Young 2010).

Including non-formal qualifications in NQFs as epistemically equal to higher education qualifications continues to be robustly debated and "re-contextualised". By identifying the precise legal and regulatory practices for "management" of non-formal qualifications vis-á-vis NQF and Qualifications Registers in seven countries for this paper, it is possible to begin to question assumptions and to gain meaningful insights into the uniqueness of each context and the sensitivities among the main players, perhaps with the potential to generalise from the particular.

\section{Unfortunate Nomenclatures Underpinning Policies for Inclusion in NQFS}

Of immediate relevance to the topic of this paper, including epistemic and territorial aspects, is how RPL/VNFIL/RVA (recognition of prior learning/validation of non-formal learning/recognition, validation and accreditation) is conceptualised and relevant policies encouraged, without unsettling the distribution of power in the architecture of NQFs.

European Union (EU) member states are expected to have national policies in place regarding validation of non-formal and informal learning (VNFIL) by 2018 under the 2012 European Council Recommendation, December 2012 (2012/C 398/ 01). The process of developing these policies and making the necessary organisational and financial arrangements to implement them thereafter requires consultation with and agreement among a wide range of stakeholders. From the 
perspective of this paper, it includes decisions regarding how non-formal qualifications achieved outside state-supported education and training will interface with the sub-frameworks of national frameworks of qualifications (NQFs), thereby opening up frameworks beyond qualifications achieved within the formal sectors. It will also involve consideration of where non-formal qualifications interface with the three-cycle Bologna structure in higher education in general, as well as how the nomenclature recognition of prior learning (RPL) might need to be re-considered as a much wider policy instrument across the European Higher Education Area (EHEA) with inevitable consequences for quality assurance systems in individual higher education institutions as well as for the European Association for Quality Assurance in Higher Education (ENQA).

Since 2012, there has been considerable stakeholder positioning and debate in anticipation of the 2018 policy development deadline. From the analysis of relevant policy documents and academic literature it is evident that there are a number of powerful policy influencers determining the likely direction of VNFIL, as well as cautionary voices arguing for greater clarity with regard to how non-formal qualifications are defined and quality assured for inclusion in NQFs, together with calls for conceptual and operation separation of "non-formal learning" from "informal learning" in policy instruments. There are calls too for accurate data about and understanding of the precise reality of how non-formal qualifications achieved outside state-supported systems are currently managed within early generation and newer NQFs in Europe.

\section{The Narrative and Ideologies of Lifelong Learning and RPL/VNFIL Policies}

The genesis of policies to value learning and knowledge acquired outside formal education and training is frequently attributed to the ideologically humanistic positions of the UNESCO Faure Report (1972) Learning to Be and the Delors Report (1996) Learning: The treasure within which, to some degree, influenced World Bank (WB) policy interest in education and the liberal, adult education, lifelong learning movements of the late 1980s and 1990s. That era also witnessed the movement for accreditation of experiential learning (APEL) across both vocational and higher education levels. Elfert (2016) argues that both the Faure and Delors reports were "unfailures": paradoxically failing as political and social movements in their time but sustained as prophetic visions for future generations. She further argues that UNESCO gave up on its vision of lifelong learning and shifted to more utilitarian ideals as evidenced in the 2015 report: "Rethinking Education: Towards a Global, Common Good?".

She also argues that there have been too many competing international organisations in the lifelong learning policy space, including the OECD and World Bank, which are influencing governments, in particular neo-liberal directions, with regard 
to non-formal and informal learning provision. Singh (2009) likewise notes a significantly growing divide between lifelong learning policies in the global North and global South to the extent that currently there is less policy-borrowing by the South where the non-formal and informal sectors are more significant than the formal education and training sectors. Likewise, Wheelahan (2011) warns countries of the global South against unquestioned replication of qualifications framework models from Anglophone countries where there is both conceptual and policy differentiation between formal qualifications and non-formal qualifications.

In Europe, there is evidence of conceptual, policy and linguistic divergence regarding the "status" of non-formal learning and appropriate recognition systems among bodies which champion vocational qualifications such as Cedefop, European Training Foundation (ETF), International Labour Organisation (ILO) and the European Qualifications Framework (ETF) on the one hand, the private/market qualifications sector on the other hand, with higher education interfacing with both in different contexts. These divergences are evident in publications such as inventories, research project reports, and conference proceedings.

A central locus of contestation is the increasing reliance of qualifications frameworks and recognition systems on the learning outcomes paradigm.

\section{The Learning Outcomes Debate}

Policy, explanatory, promotional and critical literature surrounding the use of learning outcomes to define and design qualifications and qualifications frameworks is indeed vast. For the purpose of this paper, it is probably sufficient to note the ideological and educational objections articulated by academics and which are likely to influence VNFIL policies, and how inclusion of non-formal qualifications in national frameworks is regarded by the higher education sector-assuming that the sector articulates a coherent and unified worldview in this regard. The critical issues which incite polemic debate include the following: learning outcomes reflecting marketisation of education (Allais 2007), the neglect of knowledge (Allais 2014; Hussey and Smith 2002, 2008), the negative impact on student learning (Noonan 2016), managerial instrumentalism at the expense of the learning process and yielding of autonomy to "European competence creep" (Bohlinger 2012; Elken 2016; Falkner et al. 2004, 2005; Gallagher 2002; Pollack 2000a, b), assumption of transparency (Cort 2010; Elken 2015), standardisation creep (Maassen and Musselin 2009), unsustainable distance between learning outcomes design and real world teaching and learning contexts (Blackmur 2007; Kerry et al. 2014), using learning outcomes as performance indicators (Stewart 2010), abstract level of graduate learning outcomes and rapid obsolescence (THEM 2012). 


\section{Persistence of the Non-formal/Informal Learning (VNFIL) Nomenclature}

The nomenclature "VNFIL" belies the conceptual and linguistic reality that non-formal "qualifications" differ in all aspects from non-formal and informal/ experiential learning. In higher education, it is normal practice to distinguish between certificated prior learning and non-certificated, experiential learning when evaluating applications for access or award of credits. (FIN 2011). Likewise, the concept of experiential learning has been well theorised and woven into university assessment and pedagogical practices (Geoghegan 2005).

However, there has been enduring and uncritical use of the combined "non-formal and informal" terms permeating significant policy literature emanating from Cedefop, the EQF, the ILO and OECD, and in how inventories of policies and practices are designed and reported. Of relevance to this paper is Villalba and Bjornavold (2017) who argue that the definitional "norm" of the nomenclature nonformal and informal learning has already been achieved, as has consensus on how such learning is to be validated. They argue that the terms and processes for VNFIL have passed through the phase of "norm emergence" and "norm cascade" in Europe and have now reached the "tipping point" toward "norm internalisation." i.e. the definition and the validation process are "fully accepted and are no longer part of the public debate". This assumption, however, is not universally supported either in the broader policy literature or in the findings from the NQF-In country reports discussed later below.

\section{The Reality of Non-formal Qualifications as a Discrete Sector}

Singh and Duvekot (2013) describe a complex landscape of non-formal learning and its relationship with qualifications frameworks across country reports for Africa, the Arab region, Asia and Pacific, Europe, Latin America and the Caribbean. They conclude that Europe is more concerned with non-formal qualifications that relate to the labour market than are other regions, reflecting the European policy interest in frameworks as managerial instruments to organise human resources, mobility of labour and economic capital. This reflects the emerging definition of non-formal learning and related qualifications promoted by the OECD as "learning activities that take place outside the formal system such as those carried out within companies, by professional associations, or independently by self-motivated adult learners". Likewise, the EU Parliamentary Assembly, as far back as 1999, recognised the discrete nature of the non-formal education and training sector and the need for supportive policies at national levels:

"The Assembly recognises that formal educational systems alone cannot respond to the challenges of modern society and therefore welcomes its reinforcement by non-formal educational practices. The Assembly recommends that governments and appropriate 
authorities of member states recognise non-formal education as a de facto partner in the lifelong learning process and make it accessible for all." 15 December Document 8595.

The focus on non-formal learning in workplaces was explicitly researched in the Leonardo da Vinci project Managing European diversity in lifelong learning: the many perspectives of the validation of prior learning in the European workplace and reported in Dovecot et al. (2007) with over two-hundred case studies from eleven countries.

Of immediate relevance to this paper was the Dublin 2013 Conference "Quality Assurance in Qualifications Frameworks” organised by Qualifications and Quality Ireland (QQI) during the Irish Presidency of the EU, and the 2014 EQF conference "Making learning visible" in Birmingham UK. The Dublin conference explicitly posed the question to experts and participants: "Are national and centralised public quality assurance and qualifications bodies too closely linked to the formal education and training systems, and does that diminish their capacity to operate validation systems in a sufficiently flexible manner?" While the recorded discussion on this question shed significant light on the range of competing ideologies and views from higher education, it is worthwhile noting the eleven conclusions and areas for follow-up from the conference, three of which relate to the wider use of learning outcomes. The ninth conclusion/recommendation has two elements, the first of which is: "Member states should design or extend their NQFs to accommodate quality assured qualifications arising from outside the formal systems." What is noteworthy is that the terminology infers "non-formal qualifications" and excludes informal learning as an integrated element.

The 2014 EQF Birmingham conference proceedings include multiple case-study presentations from the non-formal qualifications sector, both private and not-for-profit, illustrating if, why/why not, and how they have arranged to have their qualifications included in qualifications frameworks.

The ENQA conference "How European QA agencies deal with recognition: findings from the ENQA working group VII on QA and Recognition", held in Dublin in June 2017, is also remarkable in that its focus was entirely towards managing internal systems arising from Bologna-related recognition of degrees and periods of study. There is no reference to the 2108 deadline for VNFIL policies or to implications for widening the scope of national frameworks (Chaparro 2017). This stance to an extent reflects the many models of NQF which involve higher education exclusively, or VET exclusively, and reflects the complexity of the landscape in the EHEA together with the slow pace of development of comprehensive, integrated NQFs. 


\section{Results of the NQF-iN Project}

The NQF-IN project produced seven EU Country Reports regarding how non-formal qualifications are included in national qualifications frameworks (NQF-IN 2017). Three are first generation frameworks countries: Ireland, Scotland, France. Four have only recently adopted their NQFs or are at the advanced stage of implementation: Poland, Czech Republic, Hungary and Croatia. Analysis of the reports is at an early stage at the time of writing.

From the perspective of higher education's involvement in the inclusion process, if any, analysis of the country reports for this paper was based on the following questions:

- Are NQF levels open to all types of qualifications or are they confined only to formal education qualifications (general education, VET, HE)?

- Can non-formal qualifications sit at the same levels as HE qualifications (i.e. on $\mathrm{NQF}$ levels equivalent to bachelors, masters and doctorate degrees)?

Table 1 Different approaches to defining "formal" and "non-formal" qualifications

\begin{tabular}{l|l|l|l|l|l}
\hline & $\begin{array}{l}\text { Awarded } \\
\text { within the } \\
\text { formal } \\
\text { education } \\
\text { system } \\
\text { (general, } \\
\text { VET, HE) } \\
\text { and } \\
\text { regulated } \\
\text { by laws or } \\
\text { by-laws }\end{array}$ & $\begin{array}{l}\text { Awarded by } \\
\text { public } \\
\text { institutions } \\
\text { (outside } \\
\text { formal } \\
\text { education } \\
\text { sector) or } \\
\text { bodies } \\
\text { accredited } \\
\text { by these } \\
\text { institutions, } \\
\text { normally } \\
\text { regulated by } \\
\text { laws or } \\
\text { by-laws }\end{array}$ & $\begin{array}{l}\text { Awarded by } \\
\text { companies, } \\
\text { sectoral } \\
\text { organisations, } \\
\text { crafts } \\
\text { chambers- } \\
\text { not normally } \\
\text { regulated by } \\
\text { laws }\end{array}$ & $\begin{array}{l}\text { Awarded by } \\
\text { private } \\
\text { training } \\
\text { institutions } \\
\text { (including } \\
\text { international } \\
\text { organisations) } \\
\text { Not normally } \\
\text { regulated by } \\
\text { national laws }\end{array}$ & $\begin{array}{l}\text { Included in } \\
\text { the NQF and/ } \\
\text { or the } \\
\text { National } \\
\text { Register of } \\
\text { Qualifications }\end{array}$ \\
\hline $\begin{array}{l}\text { Formal } \\
\text { qualification } \\
\text { (also called: } \\
\text { state/ } \\
\text { government } \\
\text { qualifications }\end{array}$ & Yes & Yes or No & Yes or No & No & \\
\hline $\begin{array}{l}\text { Non-formal } \\
\text { qualification } \\
\text { (also called: } \\
\text { private } \\
\text { market } \\
\text { qualifications }\end{array}$ & Yes or No & Yes or No & Yes or No & No & Yes or No \\
\hline
\end{tabular}


- What is the process of including non-formal qualifications in the national register?

- How is the quality of non-formal qualifications assured?

\section{Working Definitions}

There are different terms used across Europe to define qualifications awarded outside the traditional school system. For the purpose of comparative analysis Table 1 offers a synopsis of approaches to the definitions of "formal qualifications" and "non-formal qualification" used across the different national qualifications system:

Having analysed the processes used for inclusion of non-formal qualifications adopted in the NQF-IN partner countries, it is evident that the main criterion to distinguish different types of qualifications is the legal basis of the qualifications in the national qualifications system and inclusion in the register of qualifications. For example, if the process of awarding a qualification is regulated by legal acts, then this qualification will fall into the category of state regulated qualifications. Other qualifications also exist, whose awarding process is not regulated by legal acts. These qualifications are usually awarded according to the principle of "the freedom of economic activities". These qualifications would fall into the category of nonstate regulated qualifications. Within the category of state regulated qualifications, it is essential to distinguish state regulated qualifications awarded in the education system and state regulated qualifications awarded outside the education system, as the process of including these types of qualifications might differ.

Three generic types of qualifications can be distinguished across the country reports.

Qualifications Type A are regulated qualifications awarded in the formal, state-supervised education system either by public or private providers. The key characteristic of this type of qualification is that its functioning is governed by education laws.

Examples include certificates for completion of secondary school, the matura qualification, or a bachelor degree.

Qualifications Type B are state regulated qualifications awarded outside the education system regulated by legal acts or directly by ministries or government agencies but are not qualifications awarded in the formal education (school) system.

Examples are tax consultant, gas installer, building energy regulator.

Qualifications Type $\boldsymbol{C}$ are non-state regulated qualifications whose functioning is not regulated by legal acts. These qualifications are usually awarded by private providers or voluntary bodies.

Examples could be tour guiding, certificate of risk management in banking, tennis coach. 


\section{What Qualifications Might Be Included in the NQF?}

Essentially, both Types B and C could be defined as non-formal qualifications, though Type B is rarely included in the nomenclature of "non-formal and informal learning" for validation and NQF inclusion purposes in policy literature or in inventories of practice (Cedefop, ETF, UNESCO 2015, p 10).

In the NQF-IN project countries, three inclusion model solutions can be distinguished:

Inclusion Model 1: NQFs are mostly populated by Type A and Type C qualifications. This is the case of Ireland and Scotland and, to some extent, in the Czech Republic.

Inclusion Model 2: NQFs include some Type A and Type $\mathrm{C}$ with a majority of type B qualifications as is the case of France and Poland.

Inclusion Model 3: NQFs include all the school/college qualifications-type A qualifications and some type B qualifications. At present, Hungary falls into this category, and there are plans to develop procedures to include other Type B and Type $\mathrm{C}$ qualifications.

It should be noted that a fourth inclusion model could be distinguished in which $\mathrm{NQFs}$ are limited only to school/college qualifications-type A qualifications. According to the Global Inventory of Regional and National Qualifications Frameworks (UNESCO, ETF, Cedefop 2015) that is the dominant model across the countries implementing NQFs.

\section{Are Non-formal Qualifications Blocked from Higher Levels of NQF? Does HE Have a Monopoly for Higher Levels of the NQF?}

In the seven study countries there are some barriers with regard to assigning non-formal qualifications to higher levels of the NQF. This is not unusual as a number of countries working on the adoption of NQFs higher levels excludes non-formal qualifications (Cedefop 2015). With regard to relations between higher education qualifications and non-formal education qualifications, solutions in France, Poland are worth noting.

In the French system, only vocational qualifications may, technically, be included in the NQF register. Therefore, general education qualifications such as the general baccalauréat are normally excluded from the NQF. When implementing the French NQF there was a debate as to whether all higher education diplomas deemed to be vocational qualifications in nature should be included, and if those qualifications of a more academic nature (the general bachelor degree, for example) should be excluded. Initially, it seemed that there would be no place for university level qualifications in the French NQF. Eventually, the Commission Nationale de la Certification Professionelle (CNCP) - the central French institution 
responsible for governing of the NQF-reached an agreement with representatives from the Ministry of Higher Education which did not want to see any distinction made between different higher education qualifications. As a result, bachelor level higher education qualifications can be included in the French NQF.

In Poland, the Ministry of Higher Education and Science was fearful that allowing assignment of non-formal education qualification to higher levels of the NQF might encourage students to abandon the acquisition of skills in the formal education system in favour of smaller, specialised non-formal qualifications that have been assigned high NQF levels. For example, a learner might choose to take a non-formal qualification as a financial broker and drop out of the university system. The non-formal sector was seen as a threat to Polish higher education institutions. To counter this perception of the Ministry of Higher Education and Science, NQF levels of all full formal qualifications in the Polish qualifications system have different graphic emblems for the level of the qualification on certificates and diplomas (Sławiński and Dębowski 2013). Whether this differentiation illustrates university gatekeeping and hegemonic positioning or not is an interesting question. Additionally, the NQF Law in Poland says that qualifications awarded outside of higher education that are assigned to level 6 and above can be consulted with the Ministry of Higher Education and Science to ensure that the level has been adequately defined. At first, the Ministry of Higher Education and Science wanted to have the power of approving all non-formal sector qualifications which were assigned to level 6 and above, but there was no governmental consent to introduce this solution.

The Scottish NQF is an example of a framework which does not pose any restrictions to the levels of non-formal qualifications. Non-formal qualifications can be placed at any appropriate level from 1 to 12 as long as they meet the level descriptor for that level and also meet the four criteria as described in the SCQF Handbook regarding: (a) learning outcomes, (b) duration of the programme (at least 10 notional learning hours), (c) are subject to internal and external quality assurance, (d) and are formally assessed. In Scotland, there is no restriction as to the type of organisation which can apply to a CRB to get a programme credit rated. As a result, programmes owned by employers, trade unions, community groups, professional bodies and others might all be included in the NQF and may sit on the same levels as higher education diplomas.

\section{The Process of Including Non-formal Qualifications in the National Register?}

Including non-formal qualifications in NQFs, especially type C qualifications, is usually organised following an application by the provider. This means that inclusion is not automatic and legally-based as is the case for Type A and some Type B qualifications. In the NQF-IN project countries, the process of inclusion is 
centralised. In all countries, general rules for the process of inclusion are set at national level. However, the degrees of centrality vary. Three generic models of governance and organisation of the process of inclusion can be distinguished.

Institutional model 1: One central institution is responsible for accepting applications, for analysing them, and for making the decision whether to include qualification in the NQF or not. This is the case of Ireland where Quality and Qualifications Ireland (QQI) is the state agency responsible for including qualifications in the NQF database. Similarly, the central institution CNCP operates in France. CNCP analyses requests for including qualifications in the French registry of qualifications and makes recommendations to the relevant Ministry which then makes the final decision. It should be noted, however, that French solutions envisage situations in which providers operating at the regional level submit the request for inclusion to the regional institutions which conduct the first assessments. Even if the request was submitted regionally, the procedure moves to $\mathrm{CNCP}$ which gives the formal recommendation to the Ministry.

Institutional Model 2: Submitting bodies approach one intermediary institution which delegates submission requests to different institutions responsible for analysing proposals based on their area of expertise. Poland is an example of this process where all requests to include market qualifications are submitted to the institution operating the NQF registry. Currently, it is the Polish Enterprise Development Agency (PARP). PARP assesses the formal aspects of the application and then electronically transmits a completed application to the relevant ministry. The ministry reviews the submitted application and makes a determination.

Institutional Model 3: Submitting bodies might approach different institutions which will assess their application in the process called "third party credit rating". This is the case in Scotland where providers may select a credit rating body based on their preferences. ${ }^{1}$ The credit rating body assesses the submitted application and if the decision is positive, relevant information is passed to the Scottish Credit and Qualifications Framework Partnership (SCQFP) which manages the Scottish Register.

\section{Quality Assurance of Non-formal Qualifications}

With regards to quality assurance of non-formal qualifications included in the NQF, there is a diversity of institutional arrangements among NQF-IN project countries with different institutions involved in this process.

In Scotland, SCQF Partnership along with Credit Rating Bodies are responsible for ensuring the quality and integrity of the SCQF. Principles relating to quality

\footnotetext{
${ }^{11}$ It is important to stress that not all credit rating is third party credit rating as there are a number institutions of in Scotland which can credit rating their own qualifications, e.g. Scottish Qualifications Authority, Institute of Chartered Accountants in Scotland, Scottish Police College.
} 
assurance for all qualifications (including non-formal education qualifications) in Scotland are defined in the SCQF Handbook developed by SCQF Partnership. The method of application of these principles varies from sector to sector but all Credit Rating Bodies are required to operate quality assurance systems that include robust checks carried out by an independent body or someone who is not employed by, or part of, the institution or organisation. As the system of credit rating is a devolved one, it is important that there is a quality assurance system to monitor this process. This is carried out by a number of agencies: Education Scotland for further education colleges; Quality Assurance Authority (QAA) Scotland for Higher Education Institutions and Universities; SCQFP for other Approved CRBs; Scottish Government and an independent auditor in the case of Scottish Qualifications Authority (SQA). All of these quality assurance arrangements include regular evaluation of the organisations, their learning programmes and their quality assurance systems.

In Ireland, Quality \& Qualifications Ireland (QQI) is the national agency responsible for assuring the quality of qualifications included in NQF. Under the 2012 Qualifications and Quality (Education and Training) Act, QQI had become both an awarding body and a quality assurance regulator across the ten levels without a demarcation now between further education and higher education. Quality assurance requirements are intended initially for approval of a provider's competence and capacity to meet those requirements. If a provider successfully proves that competence and capacity, then the provider is free to apply for approval to offer programmes leading to qualifications/awards. All providers of QQI qualifications/awards must apply for access/permission to provide such programmes. Guidance is available on the process and how to apply for permission to submit programmes for validation. Feedback from stakeholders indicated strongly that a single, unitary set of QA guidelines across all ten levels would favour HE providers unfairly. Consequently, there are now four sets of QA guidelines in Ireland: statutory QA guideline; core guidelines for all providers; sector-specific guidelines; topic-specific guidelines.

In France, quality assurance is located at the provider level. The Ministry of Education along with $\mathrm{CNCP}$ is responsible only for the coordination of this process and assurance of general guidance. Organisations which own and award qualifications are responsible for their quality. The CNCP's remit does not include carrying out rigorous quality control checks. $\mathrm{CNCP}$ ensures that, when the application for the inclusion of a qualification is submitted, it contains all documents relating to the charters, conventions and regulations regarding quality assurance, together with the conditions for issue of the qualifications in question. In this way, and only in this way, CNCP can act as a quality assurance body for qualifications which are not yet included in the register. So, the procedure for inclusion in the register is akin to a quality assurance check and there is no "external" dedicated quality assurance procedure covering the issuing of diplomas, degrees or other qualifications. It might be said that the functioning of the French qualifications system is based on a firm assumption that all those institutions and bodies, including assessors, fully comply with expectations, standards and regulations. So, it is a kind of "contractual" quality 
assurance based on a priori commitments. It should be added, however, that the procedure of including qualifications in the French register is rather demanding - an awarding body, among others, must prove that a qualification is in demand on the labour market by providing details of employment obtained by learners from the groups of graduates for the last three years. This criterion provides a means of determining the relevance of qualification on the labour market and serves as an exante quality check: if there is no demand on the market for this qualification (either because of lack of labour market relevance or poor quality of provider) it cannot be submitted to the registry.

In Poland, the system of quality assurance for non-formal education qualifications included in the NQF had to be developed from scratch. New systemic solutions for ensuring the quality of qualifications came into force with the Integrated Qualification Systems Act of 22 December 2015. The Act does not impact on the principles or mechanisms of quality assurance in the formal general, vocational and higher education systems.

Quality assurance of non-formal sector qualifications consists of overseeing the validation and certification processes, which are the responsibility of the relevant ministry. Awarding bodies are obliged to submit activity reports to the relevant ministries at least once every two years. Each awarding body functioning outside the formal general, vocational and higher education systems that wants to award qualifications to be included in the NQF must have internal and external quality assurance systems for their validation and certification activities. The ministry coordinating the integrated qualifications system maintains a list of institutions authorised to provide external quality assurance and announces a call for institutions to join this list at least once every three years. The relevant ministry for a given qualification appoints an external quality assurance institution (EQAI) by signing an agreement with the institution.

External quality assurance consists essentially of conducting regular external evaluations of validation and certification in the awarding institution and of its internal quality assurance system.

In the Czech Republic, the main coordinator role in the process of assuring the quality of qualifications included in the National Register of Qualifications (NSK) is the Ministry of Education with other ministries responsible for particular fields of activity.

The Ministry of Education coordinates the activity of central administrative bureaux (ministries) in accordance with the law and approves the content and form of all NSK qualifications. Other Ministries and authorising bodies participate in the development of the qualification standards, deciding on granting, extending validity, or revoking the authorisation to award qualifications. Ministries are responsible for the supervision of the authorised bodies, and maintenance of a register of examination results of authorised bodies, including the register of certificates granted. An authorised body can be any individual or organisation that fulfils the criteria set by law. These entities are authorised by the respective ministries according to their field of activity, e.g. Ministry of Labour and Social Affairs 
authorises in the area of labour law relations, work safety, employment, pension security, social care.

In the Czech Republic, the important role in quality assurance is played by sectoral councils which bring together employer and employee representatives. The sector councils develop occupational standards which are the basis for qualifications development and are expected to be proactive in suggesting what new standards are needed and where standards should be updated.

In Hungary, all qualifications included in the NQF are embraced by the quality assurance system developed at ministerial level and regulated by the relevant legal acts. Non-formal sector providers operating in the adult education sector can have their programmes accredited (so-called vocational programme requirement-VPR) and included in the NQF by way of dedicated procedure managed by the Hungarian Chamber of Commerce and Industry - a public body functioning under the supervision of Ministry of Economy. Each institution licensed to award VPR qualifications needs to perform self-assessment according to the processes and indicators in the internal quality assurance plan which is subjected to the external assessment at least once every four years. The VPR system is a new element of the regulation of adult training in Hungary introduced only some year ago. The aim of introducing the VPRs was to establish uniform requirements and recognition for non-state vocational training to increase transparency and "prestige" of non-formal qualification on the labour market. Currently, there are discussions among stakeholders and experts in Hungary whether this new system is too regulated and whether it poses too much burden for training institutions.

In Croatia, the qualifications framework was designed in a way to allow all types and classes of qualifications to be included following the process of accreditation. However, with regard to non-formal sector qualifications, the procedures of inclusion and quality assurance have not been finalised yet. In the Croatian qualifications system, all labour market-oriented qualifications should be based on occupational standards indicating relevant skills and competencies to perform specific occupations. Similarly to the Czech Republic, the Croatian system gives an important role to the sectoral councils which are responsible for the development of occupational and qualification standards and for general harmonisation of the Croatian qualifications with labour market needs. The operations of the sector councils are coordinated by the Ministry of Education. 


\section{What Can We Conclude About Higher Education's Positionality on Inclusion of Non-formal Qualifications in NQFs?}

It is clear that the landscape of NQFs and meta-frameworks is a complex one with many vested interests and policy agendas. Arising from the selected data in this paper, there are a number of research-worthy conclusions that can be drawn, particularly the four below.

\section{Globalisation, Subsidiarity and Contextual Embeddedness?}

Regardless of the geographical scope of NQFs or meta-frameworks, the most significant determinant for the inclusion of non-formal qualifications is the local context and the degree of centrality of governance.

\section{"Re-differentiation" and "Re-contextualisation" Among Qualifications?}

It could be concluded that higher education in the EHEA countries operates within its own sector without significant distraction by policy developments in other sectors. However, this would overlook the reality that most NQFs are structured around the formal school, university and VET systems and that any other types of provider or qualifications are obliged to operate on less powerful terms. It could also be argued that higher education and the Bologna process have monopolised the design of qualifications frameworks through the Dublin Descriptors and variations thereof in more profound ways than the EQF. There is nothing new of course in these arguments: the hegemonic status of higher education remains largely unquestioned.

However, there is a subtle process of "re-differentiation" of education providers, and thus of qualifications types, going on as a result of how NQFs and the EQF are now operating. Whether this movement will make higher education more open to the non-formal sector or not is unclear at this time.

\section{"Inclusion" in NQFs as Symbolic or Substantive?}

It could be argued that NQFs and the EQF are still more symbolic than stitched into local realities where they claim to be dominant. Additional deep research is required to explore this argument. 


\section{Persistence of "Worthy" VNFIL as Access to Epistemic Capital}

With regard to the preparation for the 2018 VNFIL policy deadline, there is no evidence that ENQA is shifting from the conceptual and operational mechanism of RPL — recognition of prior learning - from its own sector-centric epistemological and procedural positionality. This is understandable.

With regard to the inclusion of non-formal qualifications in NQFs, there is some evidence that the higher education sector has undue weight in most countries with regard to naming and levelling of qualifications. This form of epistemic power is not surprising.

\section{Endnotes}

Placing these particular issues to one side, there are a number of comments which could usefully be made in relation to the purpose of this paper. Firstly, it is obvious that there is a significant chasm between the policy rhetoric regarding valuing of non-formal learning and the reality of EU practices which leave the higher education sector unchallenged. The diversity and complexity of non-formal sector qualifications across the seven country reports alone are testament to that reality. Secondly, there is no evidence that concepts and terminology around non-formal qualifications and VNFIL have reached a stage of unchallenged consensus, or that the HE sector, in general, is unsettled by them. Whether such clarity in meta-policy documents is likely to emerge is a good question, considering the high level of abstraction that permeates them and considering the ongoing message that quality of credentials is best assured by making no changes to the status quo!

So, the question is: Does it matter to the higher education sector? The answer is: Probably not in general, but it could matter in specific national contexts where access to perceived epistemic capital through credientialising powers is either blocked or enabled!

This is not to conclude that the sector is deliberately ambivalent, inert or resistant to including non-formal qualifications in NQFs: it is simply an acceptance of the complexity of education and training generally with its epistemic hegemonies and the wisdom of making haste slowly when it comes to extreme paradigm shifts and rapid Europeanisation in education and training. There are good arguments in favour of the subsidiarity principle mindfully applied.

What could be useful at this stage is additional research to establish the reality of how higher education interfaces with the non-formal qualifications sector through partnerships, joint provision or franchises in different countries, and if, in reality, higher education has something to fear from wider formal recognition of the non-formal qualifications sector and is covertly, or indeed overtly, restricting the non-formal sector's wider inclusion in NQFs. 


\section{Authors of NQF-IN Country Reports 2017}

\section{Croatia-Mile Dželalija, Snježana Knezić, Ivana Carev}

Czech Republic — Jan Brůha, Viola Horská, Miroslav Kadlec

France-Alexandre Meliva, Josiane Paddeu, Patrick Veneau and Matteo Sgarzi Hungary-Zoltán Loboda, Erzsébet Szlamka, Éva Tót

Ireland-Anne Murphy

Poland-Stanisław Sławiński, Horacy Dębowski, Sylwia Walicka, Agata Poczmańska

\section{Scotland-Anthony O'Reilly, Sheila Dunn}

Note: Permission to use data from the country reports was gained from the original authors. Interpretation of the data and all other comments are the opinions of the two authors of this chapter only.

\section{References}

Allais, S. (2007). Why the South African NQF failed: Lessons for countries wanting to introduce national qualifications frameworks. European Journal of Education, 42(4), 523-547.

Allais, S. (2014). Selling out education: National qualifications frameworks and the neglect of knowledge. Netherlands: Springer.

Blackmur, D. (2007). A critique of the concept of a national qualifications framework, 23 January 2007 based on document prepared for the fifteenth international conference on Assessing Quality in Higher Education. Cape Town

Bohlinger, S. (2012). Qualifications frameworks and learning outcomes: challenges for Europe's lifelong learning area. Journal of education and work, 25(3), 279-297.

Cedefop. (2015). Analysis and overview of national qualifications framework development in European countries: Annual report 2014. Working paper Number 27. Luxembourg.

Chaparro, T. S. (2017). How European QA agencies deal with recognition: Findings from the ENQA working group VII on QA and recognition. Paper presented at the Exploring synergies between quality assurance and qualifications recognition, Dublin, Ireland.

Cort, P. (2010). Stating the obvious: the European qualifications framework is not a neutral evidence-based policy tool. European Educational Research Journal, 9(3).

Elfert, M. (2016). Revisiting the Faure report (1972) and the Delors Report (1996). Why was UNESCO's utopian vision of lifelong learning an "unfailure"? Paper presented at the ESREA Triennial Conference Maynooth, Ireland.

Elken, M. (2015). New EU instruments for education: Vertical, horizontal and internal tensions in the European qualifications framework. Journal of Contemporary European Research, 11(1).

Elken, M. (2016). EU-on-demand': Developing national qualifications frameworks in a multi-level context. Journal of Contemporary European Research, 11(1), 69-83.

Falkner, G., Hartpall, M., Leiber, S., \& Treib, O. (2004). Non-compliance with EU directives in the member states: Opposition through the back door? Western European Politics, 27(3), 452473.

Falkner, G., Treib, O., Hartlapp, M., \& Leiber, S. (2005). Complying with Europe? The impact of EU minimum harmonisation and soft law in the member states. US: Cambridge University Press.

Fernie, S., \& Pilcher, N. (2009). National qualifications frameworks: Developing research perspectives. Quality in Higher Education, 13(3), 221-232.

FIN. (2011). Recognition of prior learning (RPL) in the university sector: Policies, case studies and issues arising. Dublin: University Framework Implementation Network. 
Gallagher, C. W. (2002). The trouble with outcomes: Pragmatic enquiry and educational aims. College English, 75(1).

Geoghegan, B. A. (2005). From personal to public learning: Philosophical, policy and pedagogical challenges of recognition of prior experiential learning (APEL) in higher education. National University of Ireland.

Hussey, T., \& Smith, P. (2002). The trouble with learning outcomes. Active Learning in Higher Education, 3(3), 220-233.

Hussey, T., \& Smith, P. (2008). Learning outcomes: A conceptual analysis. Teaching in Higher Education, 13(1), 107-115.

Karseth, B., \& Solbrekke, T. D. (2010). Qualifications frameworks: The avenue towards the convergence of European higher education? European Journal of Education, Special Issue: Ten Years of the Bologna Process: “What Futures?”, 45(4), 563-576.

Kerry, D., Brooks, S., Rawlinson, M., Jon, S., \& Robert, N. (2014). Using learning outcomes in higher education: Where is the evidence? Paper presented at the SRHE Conference.

Maassen, P., \& Musselin, C. (2009). European integration and the Europeanisation of higher education'. In European integration and the governance of higher education and research (pp. 3-14). Netherlands: Springer.

Murphy, A. (2017). Including of non-formal sector qualifications in the NQF in Ireland. NQF-IN Project Country Report.

Noonan, J. (2016). Ten theses in support of teaching and against learning outcomes. Interventions and Evocations.

NQF-IN (Ed.). (2017). Seven draft Country Reports produced by the NQF-IN Erasmus+ Project.

Pollack, M. A. (2000a). Creeping competence: The expansion of the agenda of the European Community. Journal of Public Policy, 14(2), 95-145.

Pollack, M. A. (2000b). The end of creeping competence? EU policy-making since Maastricht. Journal of Common Market Studies, 38(3), 519-538.

Raffe, D. (2012). What is the evidence for the impact of national qualifications frameworks? Comparative Education, 49(2), 143-162.

Singh, M. (2009). Informal and non-formal learning and frameworks in the development countries. UNESCO Institute for Lifelong Learning.

Singh, M., \& Duvekot, R. (2013). Linking recognition practices and national qualifications frameworks: International benchmarking of experience and strategies in the recognition, validation and accreditation (RVA) of non-formal and informal learning. Hamburg: UNESCO Institute for Lifelong Learning, Inholland University of Applied Sciences.

Sławiński, S., \& Dębowski, H. (2013). Referencing the polish qualifications framework for lifelong learning to the European qualifications framework. Warsaw: Educational Research Institute.

Sławiński, S., Dębowski, H., Poczmańska, A., \& Walicka, S. (2017). Including of non-formal sector qualifications in the NQF in Poland. NQF-IN Project Country Report.

Stewart, S. (2010). The trouble with learning outcomes: With apologies to Hussey and Smith. Paper presented to Connected 2010 2nd International Conference on design education, 28 June-1 July, University of new South Wales, Australia.

Times Higher Education Magazine. (2012). The unhappiness principle, 29 November 2012.

UNESCO, ETF, \& Cedefop. (2015). Global inventory of regional and national qualifications frameworks volume I: Thematic chapters. Hamburg: UNESCO Institute for Lifelong Learning.

Villalba, E., \& Bjornavold, J. (2017). Validation of non-formal and informal learning: A reality in Europe? In Global monitoring inventory on NQFs, volume 1: Thematic chapters. Cedefop, ETF and UNESCO 2017.

Wheelahan, L. (2011). Beware of Anglophone Countries bearing gifts. In S. Bohlinger \& G. Munchhausen (Eds.), Recognition and validation in education policy. BIBB: Bonn.

Young, M. (2010). Alternative educational futures for a knowledge society. European Educational Research Journal, 9(1). 
Open Access This chapter is licensed under the terms of the Creative Commons Attribution 4.0 International License (http://creativecommons.org/licenses/by/4.0/), which permits use, sharing, adaptation, distribution and reproduction in any medium or format, as long as you give appropriate credit to the original author(s) and the source, provide a link to the Creative Commons license and indicate if changes were made.

The images or other third party material in this chapter are included in the chapter's Creative Commons license, unless indicated otherwise in a credit line to the material. If material is not included in the chapter's Creative Commons license and your intended use is not permitted by statutory regulation or exceeds the permitted use, you will need to obtain permission directly from the copyright holder.

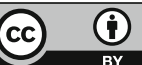

